\title{
Conflict Resolution with Management Design of Sinergy Program Revitalisation between Government, Corporation (CSR) and Society on the Basis of Economic Efficiency Corridor in East Kalimantan
}

\author{
Aloysius Hardoko ${ }^{1}$, Susilo ${ }^{1} \&$ Jawatir Pardosi ${ }^{1}$ \\ ${ }^{1}$ Faculty of Education and Teacher Training, Mulawarman University, Samarinda, Indonesia \\ Correspondence: Aloysius Hardoko Faculty of Education and Teacher Training, Mulawarman University, \\ Samarinda, Indonesia. E-mail: makrin_tindangen@yahoo.co.id
}

Received: February 19, 2015 Accepted: May, 2015 Online Published: June 21, 2016

doi: $10.5539 /$ ass.v12n7p37

URL: http://dx.doi.org/10.5539/ass.v12n7p37

\begin{abstract}
The implementation of conflict resolution phase III study showed that a win-win solution is beneficial to both sides of the conflict. The whole area is selected based on the amount of the most numerous mining and oil palm plantations which are plagued by the problem of external conflict, both with agencies and communities around the mines and plantations in East Kalimantan.

The results of the implementation indicate that the conflict resolution is done through an integrated way with the principle of "win win". This has been proven through focus group forum that has agreed on a settlement process which is not detrimental to all parties though maximum expectations are not quite achievable. Several successfully resolved cases are disputed lands (mines and plantations) and the negative impact of the exploitation of the mine.

In general, this is well received by all participants of the FGD, however, there are input / suggestions as follows: 1) the government must engage all elements and take responsibility for CSR programs that have been agreed, 2) agreed decision is not only tripartite coordination, but should include aspects of Coordination, Integration and Synchronization, 3) the Court should modify the rules based on Regional Acts, in which all decisions is not only relying on litigation, but also on the non-litigation, 4) It should incorporate aspects of mental development and HR potential of the local community through a variety of training (workshops) required by the surrounding community.

Based on observations and FGD, it shows that this design can be done and turns out to be beneficial for all parties concerned, though there is an obstacle when claims for compensation are too high (replacement land with a maximum price) whereas the companies only want to replace with a low price supported by evidences are not owned by the local residents. However, the principle of "win-win solution" works well on solving the conflict that has been happening.
\end{abstract}

Keywords: conflict resolution, management design, CSR program, empowerment in economy

\section{Introduction}

Starting from a few cases of land disputes in East Kalimantan, the areas the have experienced a lot of conflicts on oil palm plantations are in Pasir District, while Kutai has a few in coal mining. In the area of Kubar and Kutim, the cases are not as much as the conflict that occurred in Pasir District and Kutai.

Particularly in East Kalimantan, on operational plantations, mining ranks reaches around $60 \%$, both on national and international scale. Conditions such as these will definitely cause particular problems for the government and the company itself. The government can even threaten the stability and sustainability of the company because the people, especially those in the vicinity of the plantation / mining, feel that social capital in them turns out to be less accommodated and responded, either by the government or the company.

Society has yet to feel the benefits of short-term welfare fulfilment or even a long term one as they feel that the raw materials are in the area or location in which they live. This triggers the tendency for conflict and ultimately will lead to a variety of social insecurity that destabilize all parties, both in the government itself as well as on the company, let alone within the surrounding community. 
Therefore, an existence of community empowerment on various aspects of improving the welfare is urgently needed and has attracted serious attention from various parties. Seeking a resolution of the conflict as a problem-solving effort, both from governments and companies, is also fundamental.

Thus the most interesting things in an effort to seek resolution of conflict in many cases that arises is how to understand the conflict. Society has a perspective or a different view of life and its problems. It is not surprising that in the interaction between society, government and enterprise occurs a different view. Public perceptions of the social and political aspects are different from the views of the company and the government. Different viewpoints of the problems that occur relating to the lives of many people cannot be avoided and it can enrich all parties.

The differences that exist can be classified into two dimensions, namely: the dimension of the "natural" and the dimension caused by certain conditions, such as: status, power, and so on. Different views and goals are often seen as a problem that can only be resolved if all parties have the same purpose or see the difference as a resource that leads to a broader understanding of the problem and repair the situation at hand.

Concrete conditions on the ground indicate that the CSR program has been done by the company, either by coal mining companies and oil palm plantation companies in various regions in East Kalimantan. Various programs run by the company are in accordance with company management and customized design as well as with the limited ability of the company itself. Programs that have been done do provide benefits to the community, but there are benefits which are just temporary and do not provide benefits that are empowering community resources in the long term.

Often programs undertaken by the company are not in accordance with the wishes and expectations of the society. Public demand for the company often can not be met by the company for various reasons. These conditions then trigger the conflict between the company and its CSR program worsened by unfulfilled society's expectations.

This fact requires an understanding of the meaning of the conflict itself, in order to avoid an increase of conflict into violence. Therefore, the conflict should be resolved really well for the sake of the common good.

Based on these various cases, the researchers rare aware of the importance of finding a design that is ideal in order to solving the above problem. The results of the first study have produced a draft design in a form of management design of conflict resolution which can be concretely prepared based on field data, either in the form of observation, interviews and documentation there are. The results of the research were a design management, the conflict resolution that in this second phase of research has been validated and tested in the FGD. There are inputs, suggestions and proposals in the design components, so that it becomes a mutual agreement.

And in the third stages of this research, the design will be implemented directly to the location of conflict between the companies, citizens and relevant agencies in order to solve the conflict that has occurred, with the hope to resolve any problems that exist as well as to benefit all parties involved in the conflict.

\section{Method}

\subsection{Research Approach}

This study uses the paradigm of post-positivism with qualitative research approach, namely to obtain in-depth and holistic picture, looked at as a whole in the context of events (Nasution, 1988; Lexy Moleong, 2000). Researchers intend to examine the issues arising from and in the community and seeks to find alternative design management conflict resolution in an effort to resolve the conflicts that occur in the CSR program in East Kalimantan. Furthermore, in the phase 3 study, there will be conducted a concrete implementation of the design to the location of the conflict and also found real results of conflict resolution that provides an outlet for the relevant agencies involved in the conflict.

\subsection{Research Instruments}

Collecting data in this study by observation, in-depth interviews and FGD (Focus Group Discussion), the study of literature and documentation. The main method used is the in-depth interviews and the FGD (Focus Group Discussion) on the location of the conflict.

Primary data in this study is the result of in-depth discussion of data obtained directly from the Distamben and Disbun Regency / City, which includes Distamben Kutai regency, Distamben Samarinda, Disbun Paser, Disbun Kutai Barat, CSR coal and oil, then the District of , Village, as well as influential public figures, such as community leaders / indigenous and NGO (opinion leaders), coal mining companies and oil palm plantations 
that have conflicts with the community through forums FGD, so as to show harmony in conflict resolution. Secondary data in this study can be monographs, quantitative data and other data used to enrich and strengthen the results of discussions through FGD.

\subsection{Sampling}

The sampling technique in this study is conducted with a purposeful sampling pattern by using considerations or criteria. The criteria in the sampling in this study are: 1) The area has the most coal mining concession licenses and oil palm plantations in East Kalimantan, 2) Regional ring 1, the area / region close to population centers and problematic, 3) The area of the mine and oil palm plantations that have conflicts with the relevant authorities, the community around the mine area and plantation. With sampling as respondents in this study, further defined in priority conflict settlement and immediately looked vulnerable for social harmony.

This type of research is a descriptive study that is interpretative, which explains the meaning behind events in the field (Suharsimi Arikunto, 2006). This study is also a case study that can add value to the unique knowledge about an individual phenomenon, collective, organization, in the social and political aspects (Robert K. Yin, 2002). Researchers intend to study the problems arising from the conflict in the community related to the implementation of CSR programs towards social harmony and seek to find concrete results through alternative conflict resolution management design that encourages a shift towards a prosperous society.

The credibility of the data in this study is using triangulation techniques, namely checking the correctness of data on every aspect of the design of a reliable source of FGD.

\subsection{Data Analysis}

Data analysis techniques in this study is using qualitative data analysis with a discussion on the research team of the aspects in the design while taking into account the results of focus group discussions, as well as the result of decisions taken by the FGD. Next is stating that the conflict resolutions are achieved by all parties based on the FGD as a final result of the design. Furthermore, it is necessary to analyse the accuracy of the design by analysing the design components.

\section{Result}

Based on FGD result was implemented in the field, it can be concluded:

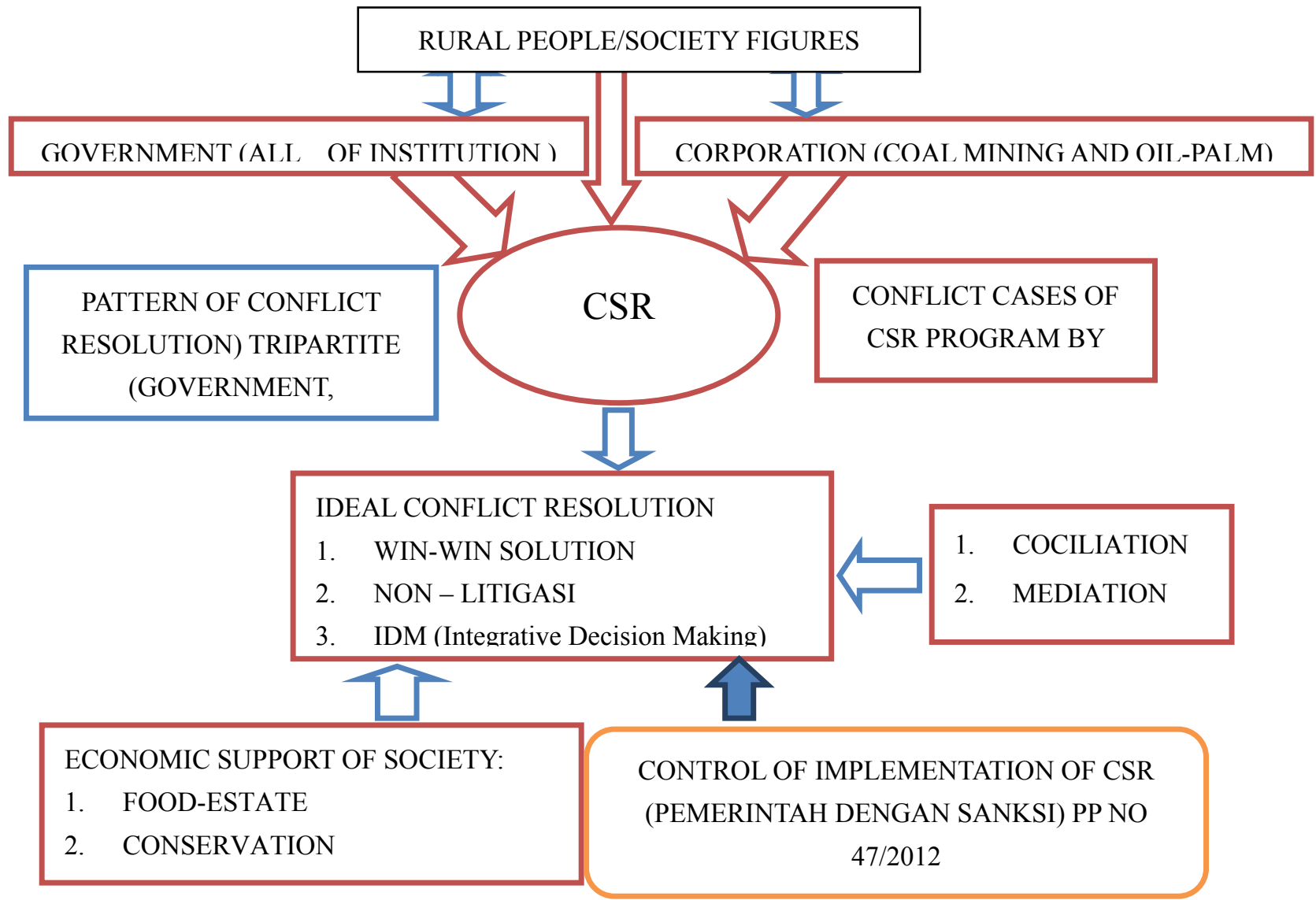




\section{Results of FGD}

Based on the results of focus group discussions which were conducted in West Kutai and Kutai, Samarinda and Paser, which was attended by various elements of society and government, namely: District Mining Office, Department of Plantation and Veterinary Office, Disperindagkop District, Coal Mining Company, Oil Palm, Village Chief, Community Leaders, and BLH District, several design implementation results are found, such as: 1) the settlement of land disputes that occurred in coal mines in Kubar and oil palm plantations in Paser is resolvable through FGD dialogue while also following the design patterns that lead to "win-win", which gives advantages to both sides. 2). Implementation of design can run through the control pattern KIS (coordination, integration and synchronization) from all sides. 3) Conflict resolution is not only solved through a clear CSR programs but also by empowering the community through a variety of exercises and capital. 3) Suggestions and recommendations generated by the FGD is that the elements of the government should take responsibility in terms of providing guidance to the residents who took part in the CSR program given to the surrounding community.

\section{Conclusion}

The conclusion of the overall results are:

1. The mechanism of the process of the CSR program planning phase should start from the stakeholders at the village level (consisting of representatives of the citizens and the community leaders, traditional leaders) by utilizing Musrembangdes as media preparation of the CSR program. This is in accordance with the needs of local residents with the allocation of CSR funds which is budgeted by the company.

2. Preparation of CSR programs bring those stakeholders, including representatives of the government (all relevant agencies), and elements of the company decision makers, and involving citizens or the public and community leaders. In terms of employment, this is referred as the "Tripartite".

3. Based on the various cases of conflict and the conflict resolution pattern desired by elements of the tripartite (government, companies, and citizens), there is a need to do various mediator ways, reconciliation process and arbitration to achieve the ideal results of conflict resolution.

4. Based on the theory study and FGD, the ideal resolution of conflicts in the design management conflict resolution can be reached through: 1) the procedure of "win-win" solution, 2) the pattern of non-litigation can be done if there is a crucial issue, without taking aside the litigation 3 ) IDM pattern (Integrative Decision Making) through dialogue in the purpose of synchronizing the perception of all parties, 4) KIS pattern (coordination, integration, and synchronization), i.e. solving conflicts through interaction and communication as a whole.

5. The results of conflict resolution done in the above patterns must be under the supervision and law enforcement of the government under Regulation N0 47/2012 and implementation of strict sanctions.

6. Conflict resolution requires follow-up in the form of economic carrying capacity of the community, namely to develop: a) Food-Estate as a form of utilization of reclaimed land mines and plantations to improve the welfare of the surrounding community, b) Conservation of natural resources associated with rare fauna and flora and that almost extinct, c) Rehabilitation of forests damaged by the exploitation of mines and plantations.

\section{Acknowledgments}

The authors would like to appreciate Directorate General of Higher Education of Indonesian Ministry of Education for the research grant provided under the Masterplan for Acceleration and Expansion of Indonesia's Economic Development Grant Scheme and University of Mulawarman, especially the Research Institution of Mulawarman University which has facilitated the research. The authors would also appreciate those who have took part and provided us with information for this research and Rexy Anderson Tindangen for preparing the manuscript.

\section{References}

Anonim. (2012, July). CSR Kembangkan Pertanian. Kaltim Pos.

Anonim. (2012, September). Food Estate Masih Tertinggal. Kaltim Pos.

Bachriadi, D. (1999). Gerakan Petani dan Tumbuhnya Organisasi Petani di Indonesia.

Batten, T. R. (1967). Communitiest and their Development. London University Press.

Irwanto. (2006). Focussed Group Discussion. Sebuah Pengantar, Jakarta, yayasan Obor.

Irwin, H. (1994). Managing Corporate Communication. Malaysia. 
Jim Ife. (1995). Community Development, Analysis and Practice. Longman, Australia.

Maria. (2013, October). Pemangku Kepentingan dalam Penyelesaian Konflik. Artikel Jurnal, 10.

Mursyid, R. (2012, September 4). Mayoritas Tambang Tidak Taat Aturan. Kaltim Pos.

Nasution, S. (1988). Penelitian Naturalistik. Jemmars, Bandung.

Noor, I. (2012, August). CSR Bisa Entaskan Kemiskinan. Kaltim Pos.

Pambudi, T. S. (2005). CSR Sebuah Keharusan dalam Investasi Sosial. Puspennas Depsos, RI, Jakarta

Sadikin, A. (2009). Implementasi Program CSR pada Masyarakat Sekitar Tambang Batu bara di Kubar (Thesis Unpublished). Unmul, Samarinda.

Solihin. (2008). Penyelesaian Konflik dalam Dunia Bisnis. Artikel Jurnal.

Undang-Undang Republik Indonesia Nomor 40 Tahun 2007 Tentang Perseroan Terbatas.

\section{Copyrights}

Copyright for this article is retained by the authors, with first publication rights granted to the journal.

This is an open-access article distributed under the terms and conditions of the Creative Commons Attribution license (http://creativecommons.org/licenses/by/3.0/). 